\title{
NESTING AND FEEDING TREE SELECTION IN THE ENDANGERED WHITE-BACKED WOODPECKER, DENDROCOPOS LEUCOTOS LILFORDI
}

\author{
MARIO MELLETTI ${ }^{1}$ AND VINCENZO PENTERIANI ${ }^{2,3}$
}

\begin{abstract}
The White-backed Woodpecker (Dendrocopos leucotos) is one of the rarest European woodpeckers and its populations have declined markedly during the last century in many European countries. The objective of our study was to investigate the selection of nesting and feeding trees by the subspecies D. l. lilfordi, a field not previously investigated. We conducted this study in a mountain area of central Italy characterized by wide and homogeneous tracts of beech- (Fagus sylvatica) forested slopes. The rate at which we detected the species was highly correlated with the mean trunk dbh of the stand; the more mature the stand, the greater the number of woodpecker detections. The White-backed Woodpecker was dependent upon trees that were mature, dead, or in an advanced degree of decay for both nesting and foraging. The habitat specialization of the species suggests that forest stand management should promote longer harvesting rotations, preserve dead and decaying trees, create new foraging sites, and prevent excessive fragmentation of forested landscapes. Received 14 February 2003, accepted 9 June 2003.
\end{abstract}

Habitat requirements regarding nesting and feeding sites are important components of habitat selection by birds and are fundamental aspects in the conservation of endangered species, particularly those species that specialize on habitats affected by severe human induced alterations, such as woodlands (Hildén 1965, Cody 1985). Modern forestry has influenced bird populations in many ways since the early 1900s, and woodpecker species are particularly vulnerable because of their dependence upon dead and decaying wood for foraging sites (Aulén 1991).

Woodpecker nest sites may be quantitatively described by the properties of the nesting tree, the nest hole, and the trees used as feeding sites (Hågvar et al. 1990). The Whitebacked Woodpecker (Dendrocopos leucotos) is one of the rarest European woodpeckers (Wesolowski 1995) and its vulnerability to extinction appears to be acute (Spiridonov and Virkkala 1997, Krams 1998). Populations of this species have declined in many countries, especially in Finland (Virkkala et al. 1993, Martikainen et al. 1998), Germany (Scherzin-

\footnotetext{
${ }^{1}$ Stazione Romana Osservazione e Protezione Uccelli, c/o Oasi Naturale WWF "Bosco di Palo," Via Palo Laziale 2, 00055 Ladispoli (Roma), Italy.

${ }^{2}$ Dept. of Applied Biology, Estación Biológica de Doñana, Consejo Superior de Investigaciones Científicas, Avda. de María Luisa s/n, Pabellón del Perú, Apdo. de Correos 1056, 41013 Seville, Spain.

${ }^{3}$ Corresponding author; e-mail: penteriani@ebd.csic.es
}

ger 1990), Norway (Håland and Ugelvik 1990), Poland (Wesolowski and Tomialojé 1986), Russia (Nazarova 1977), Spain (Fernández et al. 1994), and Sweden (Aulén 1986, 1988) where it is considered an endangered species living in isolated populations (Ahlén et al. 1978). This species, together with the Lesser Spotted (D. minor) and the Middle Spotted (D. medius) woodpeckers, was classified by Angelstam and Mikusinski (1994) as the northern European woodpecker species most sensitive to change in forest structure and composition. This is due to the fact that the White-backed Woodpecker (1) is an insectivorous forest specialist (Mikusinski and Angelstam 1998a), foraging mainly on woodboring and bark-living insects in the deadwood of deciduous trees (Ahlén et al. 1978, Martikainen et al. 1998), and (2) nests in mature, dying, or dead trees (Aulén 1988, 1991; Hågvar et al. 1990; Krams 1998). Both of these elements have been affected by the decreasing amount of mature stands of deciduous forests upon which the species depends, due to intensive forestry management (Aulén 1988, Håland and Ugelvik 1990, Virkkala et al. 1993, Fernández and Azkona 1996, Martikainen et al. 1998, Mikusinski and Angelstam 1998b, Carlson 2000).

In Italy, the subspecies lilfordi is considered "vulnerable" by Pinchera et al. (1997) and "endangered" by Calvario et al. (1999), but its status and distribution is unknown within its very limited range (southern Europe, Tur- 
key, Caucasus, and Transcaucasia; Cramp and Simmons 1985). In its Italian range this species is very restricted, probably as a consequence of a glacial relict and its association with several specific structures of beech $(\mathrm{Fa}$ gus sylvatica) forests, which are limited in availability (Pinchera 1997). This factor, together with the territory size of the species, results in low densities and sensitivity to environmental changes (Pinchera and Pellegrini 1999). The conservation of this subspecies is therefore closely related to future forest policy of Apennines beech woods, which determines the age structure of forests. Consequently, studies of nest and feeding site selection, which may influence the distribution and density of this subspecies, are urgently required.

The information available for this subspecies is scarce and limited to its distribution and breeding biology; e.g., there is no information about the present population size (Castiglia et al. 1976; Bernoni 1994; Costantini and Melletti 1992, 1994; Costantini et al. 1993, 1995). The objectives of our study were to investigate nesting and feeding tree selection by this woodpecker, and to gain information useful for the conservation of the species and the management of forested habitats upon which it depends for breeding and foraging.

\section{STUDY AREA AND METHODS}

We conducted this study from 1997 to 1999 in a mountain area of the central Apennines between the regions of Latium and Abruzzi (Simbruini-Ernici massif; $42^{\circ} 06^{\prime} \mathrm{N}, 13^{\circ} 04^{\prime}$ $\mathrm{E}$; altitude range: $900-1,800 \mathrm{~m}$ ). Wide and homogeneous tracts of beech-forested slopes dominated the study area with grazing and fallow farmland in the valleys. Above $1,900 \mathrm{~m}$, high altitude pastures replace forests. Depending upon soil conditions and microclimate, beech may be associated locally with Sycamore (Acer pseudoplatanus), Italian maple (A. opalus), common yew (Taxus baccata), and limited patches of silver fir (Abies alba). The typical forest regeneration system in this area was the shelterwood system, which is characterized by harvest of the mature stand in successive cuttings (Peterken 1996). Forestry operations generally are carried out from midSeptember to mid-April, but occasionally may take place during late spring and summer.
Harvest units are about 10 ha in size and harvests generally are based on a 20- to 25-year rotation interval (Sulli and Bernoni 1993). Dead and decaying trees, which have less production value, generally are left unharvested.

Locating woodpeckers.-We determined the presence of the White-backed Woodpecker by eliciting responses to playback of taped call notes (Cramp and Simmons 1985) during February and March, the two months preceding egg laying, when the birds are most likely to respond (Aulén 1988, Costantini and Melletti 1992). This is a common and efficient method to detect the presence of woodpeckers due to the rapid response of the species to conspecific calls (Müller 1982; Dentesani 1990; Costantini and Melletti 1992, 1994; Fernández and Azkona 1996). To detect woodpeckers and to obtain information on the distribution of the species with regard to forest structure, we established transects in all of the various ages within the stands (from about 20 years, the minimum age of coppices in our study area, to old growth stands of $>100$ years). We used aerial photographs, from which it was possible to estimate the age of forest patches on the basis of the canopy dimensions and their proximity (Penteriani and Faivre 1997), to establish transects such that they covered the various tree age classes in approximately equal proportion.

Three times during the same breeding season (1997) we sampled an overall length of $30.7 \mathrm{~km}$ of transects of a large contiguous forested area. We stopped and played the taped calls every 300-500 $\mathrm{m}$ for a total duration of $4.5 \mathrm{~min}$ at each stop. We performed each playback session from sunrise to noon. To avoid overestimating the presence of this highly mobile species (Aulén 1988), we counted two individuals only when two successive responses were obtained $>1 \mathrm{~km}$ apart (Cramp and Simmons 1985). Following the vocal contact with an individual, we searched for occupied nest trees and recent feeding trees in the stand where we obtained the response. A feeding tree was considered to belong to the Whitebacked Woodpecker only after direct observations of individuals foraging there (Costantini et al. 1995).

To test for a possible relationship between White-backed Woodpecker presence and the age of the stands, we calculated the mean 
trunk diameter at breast height (dbh) of trees in the stand in which we elicited a response (it always matched the nesting stand). We estimated mean stand dbh from the first five trees that we found between the playback point from which we obtained the bird response and the approximate direction of the woodpecker call. The only restriction to tree sampling was that the distance between successive sample trees was $\geq 100 \mathrm{~m}$ to avoid collecting data that could be spatially autocorrelated.

Nesting and feeding tree selection.-To investigate nest tree selection, we compared nesting trees $(n=40)$ to an equal number of control trees. We chose control trees randomly, but in the same stand as each nest tree (see Penteriani et al. 2001 for details), and of a dbh equal to the mean dbh of nesting trees. Thus, our control sample represented the trees available for the species. We characterized nest and control trees with seven variables: altitude (m above msl), dbh, height of the tree, height of the trunk, height of the nest hole, nest hole position (three categories: on the portion of the trunk below the canopy, in the canopy, on a branch), and degree of decay (three categories: dead tree with softened wood, live tree with evidence of decay in several places, live tree without evidence of decay or only a few dead branches).

Similarly, to investigate feeding tree selection, we compared feeding trees $(n=61)$ to an equal number of control trees chosen as described above. We characterized feeding and control trees with seven variables: percentage of trunk covered by bark, bark condition (two categories: intact and partially sloughed off the trunk), dbh, tree height, trunk height, and degree of decay (as for the nesting tree).

Statistical analyses. - To avoid pseudoreplication, we used only one nesting tree and one feeding tree per breeding pair for all analyses. We used a linear regression to evaluate the relationship between $\mathrm{dbh}$ and presence of the White-backed Woodpecker (i.e., the frequency of detection). We divided the mean stand dbh into five classes: $<20 \mathrm{~cm}, 21-30$ $\mathrm{cm}, 31-40 \mathrm{~cm}, 41-50 \mathrm{~cm}$, and $>50 \mathrm{~cm}$. We used a discriminant function analysis (DFA) to detect possible differences in nesting and feeding tree structure between those used by

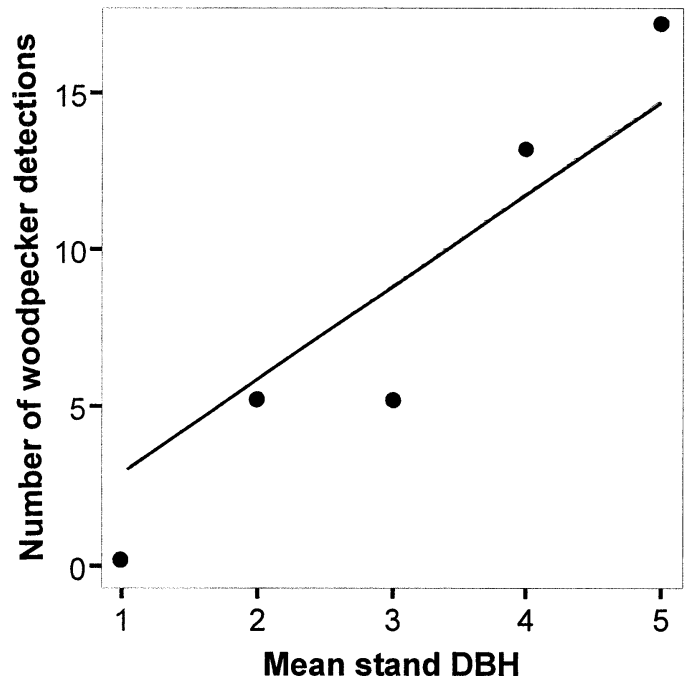

FIG. 1. Frequency of contacts with the Whitebacked Woodpecker (Dendrocopos leucotos lilfordi) increased with maturity of forest stands in beech ( $\mathrm{Fa}$ gus sylvatica) woodlands of Central Italy. The degree of stand maturity is expressed by five dbh classes: 1 $=<20 \mathrm{~cm}, 2=21-30 \mathrm{~cm}, 3=31-40 \mathrm{~cm}, 4=41-$ $50 \mathrm{~cm}, 5=>50 \mathrm{~cm}$.

the species and the control trees. We used $\chi^{2}$ analysis to test the significance of the site classification established by the DFA procedure (Sokal and Rohlf 1995), and Mann-Whitney $U$-test to compare features of nesting and feeding trees used by the woodpeckers with those of the control trees. We used the $\chi^{2}$ test to analyze the frequencies of use of several categories considered for nesting and feeding trees. When data were not normally distributed, they were $\log _{\mathrm{e}}$, square-root, or arcsine square-root transformed prior to parametric tests (Sokal and Rohlf 1995). If the data still did not approach normality, nonparametric tests were employed. All tests were two-tailed and we set statistical significance at $P<0.05$. All tests were computed using SPSS 10.0 (Norusis 1992).

\section{RESULTS}

Frequency of detections. - The frequency of detections of White-backed Woodpeckers was highly correlated $\left(r^{2}=0.94\right)$ with the mean stand dbh $\left(t_{1,3}=6.75, P=0.007\right)$. The more mature the stands were, the greater was the number of woodpecker detections (Fig. 1).

Nesting tree selection.-White-backed 
TABLE 1. Nesting trees $(n=40)$ of the White-Backed Woodpecker differed from control trees $(n=40)$ in beech stands of Central Italy, 1997-1999.

\begin{tabular}{|c|c|c|c|c|c|c|c|c|}
\hline & \multicolumn{4}{|c|}{ Nesting trees } & \multicolumn{2}{|c|}{ Control trees } & \multicolumn{2}{|c|}{ Mann Whitney $U$-test } \\
\hline & $\bar{x}$ & SD & Minimum & Maximum & $\bar{x}$ & SD & $Z$ & $P$ \\
\hline Altitude (m above msl) & 1,250 & 165 & 900 & 1,645 & 1,406 & 100 & 4.50 & 0.0001 \\
\hline Trunk dbh (cm) & 51 & 18 & 23 & 129 & 21 & 20 & 5.71 & 0.0001 \\
\hline Height of tree (m) & 25 & 6 & 5 & 28 & 21 & 12 & 3.45 & 0.0010 \\
\hline Height of trunk (m) & 18 & 5 & 4 & 22 & 16 & 5 & 0.64 & 0.5200 \\
\hline
\end{tabular}

Woodpeckers bred across a broad altitudinal range, in cavities generally located in the middle of the trunk of old trees (mean $=10.5 \mathrm{~m}$ $\pm 2.8 \mathrm{SD}$, range $2.3-12.0 \mathrm{~m}, n=40)$, characterized by large dbh values (Table 1 ). They used mainly live trees without evidence of decay $(40.0 \%)$, followed by dead trees $(32.5 \%)$, and live trees with evidence of decay in several places $(27.5 \%)$. The observed use of the above types of trees was significantly different from that expected $\left(\chi^{2}=12.2\right.$, df $=2, P=$ 0.007). Seventy-five percent (i.e., 30 of 40) of the nest holes were in the portion of the trunk below the canopy, whereas the remaining $25 \%$ were within the canopy $\left(\chi^{2}=10.0, \mathrm{df}=1, P\right.$ $=0.002)$. The most frequent orientation of the slope used for nesting was toward the northwest $(n=12)$, followed by southwest and west ( $n=8$ each), southeast $(n=7)$, northeast and north $\left(n=2\right.$ each), and south $\left(n=1 ; \chi^{2}\right.$ $=25.6, \mathrm{df}=7, P=0.001)$. The discriminant function analysis significantly $(P=0.0001)$ distinguished between nesting and control trees. Trees used for nesting generally were greater in height and dbh than control trees, and woodpeckers nested on trees located at lower altitudes (Table 1). The discriminant equation was $D=3.579-0.004$ (altitude) + $3.706(\mathrm{dbh})-0.028$ (tree height). The model correctly classified $35(87.5 \%)$ of the nesting trees and $39(97.5 \%)$ of the control trees for an overall error rate of $7.5 \%$.
Feeding tree selection.-White-backed Woodpeckers foraged primarily in mature trees characterized by variable bark conditions $($ mean $=62.9 \% \pm 35.7 \mathrm{SD}$, range $0-100 \%, n$ $=61$ ) and large dbh as feeding sites (Table $2)$. The birds mainly used live (43\%) and dead (41\%) trees, followed by trees with dead branches $(16 \%)$. The observed use of the above types of trees was significantly different from that expected $\left(\chi^{2}=7.9, \mathrm{df}=2, P=\right.$ 0.020). Of trees used for foraging, $80 \%$ were trees with the bark partially removed from the trunk, and the remaining $20 \%$ were trees showing no sign of weakness $\left(\chi^{2}=22.4\right.$, df $=1, P=0.0001)$. The discriminant function analysis significantly $(P=0.0001)$ distinguished between feeding and control trees. Trees used for feeding, although shorter than control trees, generally were greater in trunk height and dbh (Table 2). The discriminant equation was $D=-1.221-0.213$ (tree height $)+4.420(\mathrm{dbh})+0.209$ (trunk height). The model correctly classified $59(96.7 \%)$ of the feeding trees and $58(95.1 \%)$ of the control trees for an overall error rate of $4.1 \%$.

\section{DISCUSSION}

Frequency of contacts.-The correlation of mean stand dbh (as an index of stand maturity) and frequency of contacts of the Whitebacked Woodpecker suggest a dependence upon mature stands. A similar relationship be-

TABLE 2. Feeding trees $(n=61)$ of the White-Backed Woodpecker differed from control trees $(n=61)$ in beech stands of Central Italy, 1997-1999.

\begin{tabular}{|c|c|c|c|c|c|c|c|c|}
\hline & \multicolumn{4}{|c|}{ Feeding trees } & \multicolumn{2}{|c|}{ Control trees } & \multicolumn{2}{|c|}{ Mann Whitney $U$-test } \\
\hline & $\bar{x}$ & $\mathrm{SD}$ & Minimum & Maximum & $\bar{x}$ & SD & $Z$ & $P$ \\
\hline Trunk dbh (cm) & 41 & 19 & 16 & 130 & 20 & 10 & 5.54 & 0.0001 \\
\hline Height of tree $(\mathrm{m})$ & 12 & 6 & 1 & 25 & 19 & 3 & 5.96 & 0.0001 \\
\hline Height of trunk (m) & 8 & 4 & 1 & 18 & 7 & 3 & 2.20 & 0.0280 \\
\hline
\end{tabular}


tween woodpecker occurrence and stand age (characterized by dbh) was reported by Bernoni (1994), and by Pinchera (1997) who never detected the species in coppices (i.e., early successional forest stands of small-diameter stems, formed from the sprouting of new young trees from existing stumps and root stock of harvested trees). Other researchers examining woodpecker presence and forest structure consistently found similar associations with the oldest stages of stand growth, characterized by large numbers of old trees and large dbh values (Fernández and Azkona 1996, Mikusinski and Angelstam 1998a, 1998b). Costantini and Melletti (1992) demonstrated that the distribution of White-backed Woodpeckers in the study area was strictly related to the heterogeneity of the stand structure (i.e., stands with trees highly diversified in age and decay conditions).

Nesting tree selection.-Although this species occupied a large altitudinal range, as reported by Fernández et al. (1994) in Spain and Grangé (1993) in France, the woodpeckers in our study used the highest elevation belt of the Apennines beech forest for breeding. This pattern, also observed by Pinchera (1997), could not be random for the beech forest of the Italian Apennines. In fact, the highest belts of these forests (about 1,300-1,600 m above msl) correspond to areas with the most of mature trees and oldest stands, due to the concentration of past timber harvests in the more accessible lower belts of forest, and a less favorable climate for beech above about 1,600 m (Penteriani and Faivre 1997). A similar influence of the combination of human and climatic factors on the altitudinal distribution of this woodpecker also was suggested by Fernández and Azkona (1996).

Our analyses confirmed the selection of mature trees with large dbh values for excavating nest holes, as reported by Hågvar et al. (1990). Use of younger stands has been reported only by Krams (1998), who found $\leq 23 \%$ of the nesting trees were in mature stands. The author attributed this pattern to the relatively young age of the forest stands in his study area, which is considered a cause of the decline of the species in the Latvia population. The apparent dependence of this species upon large trees also could reflect that large trees are more likely than small trees to contain dead wood.

The White-backed Woodpecker usually uses dead trees for excavating its nest hole (Aulén 1988, Hågvar et al. 1990, Krams 1998), although in our study area we detected a relatively frequent use of fully vital trees, which also was observed by Hågvar et al. (1990) and Pinchera (1997). Although the frequent use of vital trees might be related to their availability, this finding supports the hypothesis that, depending on the specific hardness of each tree species, some trees may be used even if not dead or in an advanced degree of decay (Aulén 1988). However, we cannot discard the possibility that apparently healthy trees may be partially weakened by fungi; early stages of fungi parasitism usually are difficult to detect because of the absence of external trunk damage, even if internal wood is already softened by decay (T. Wesolowski pers. comm.).

The mean nest hole height was the same as reported by Pinchera (1997) and Hågvar et al. (1990), and similar to the most frequent height reported by Kram (1998), although a greater mean height $(17.8 \mathrm{~m})$ was reported by Wesolowski and Tomialojć (1986) in Poland, attributed to the height of the trees available in Bialowieza. White-backed Woodpeckers appear to select western and especially northwestern slopes, which correspond to the best exposure for beech growth (Penteriani and Faivre 1997).

Feeding tree selection.-Similar to nesting trees, the feeding trees selected had large dbh values, although their mean height was less than control trees. This result was influenced by the fact that several trees used as feeding sites were stumps, broken by wind or snow, or destroyed by insects and fungi. Our data lend further support to the hypothesis that White-backed Woodpeckers, which specialize on the larvae of xylophage insects, are dependent upon dead and highly decayed trees that attract this specific food resource (Matsuoka 1979, Aulén 1991, Mikusinski and Angelstam 1998b); such trees also characterize the nesting stands of this woodpecker (Aulén 1988, Fernández et al. 1994, Pavlík 1999). The importance of dead trees also was emphasized by Carlson (1998), who demonstrated a positive relationship between the density of dead 
trees and feather growth in the White-backed Woodpecker, the latter being considered an index of the bird's nutritional condition. Nevertheless, as also suggested by Carlson (1998), the relatively large number of living trees we found as feeding sites is not surprising, considering the insect-rich dead and decaying branches they can carry, which make them attractive to White-backed Woodpeckers (Aulén 1988).

Conservation and management implications.-The White-backed Woodpecker declined markedly during the last century in many European countries, particularly due to habitat loss associated with timber harvesting. Moreover, the endangered subspecies lilfordi represents a very localized endemic of the southern European montane forests (Voous 1947). The data we present corroborates the nesting and feeding site specialization of this species, and leads us to make the following recommendations. (1) Timber harvesting rotations, currently 20-25 years in our study area and other European countries, should be lengthened. (2) Older dead and decaying trees within each stand should be preserved; as these trees are of little harvest value, such preservation represents virtually no economic loss. (3) The possibility of creating new foraging sites by killing deciduous trees, consequently increasing insect abundance, should be evaluated. Finally, (4) fragmentation of the forest should be prevented to avoid reducing the original woodpecker population to isolated subpopulations confined to small patches of suitable habitat. Such fragmentation, along with habitat degradation, probably has increased the White-backed Woodpecker's susceptibility to extinction (Aulén 1988, Tiainen 1990, Carlson and Aulén 1992, Krams 1998).

Until recent years, the Apennines forests of Central Italy provided favorable and unfragmented habitat for the species, undoubtedly one of the most important in Europe. This region supported extensive beech forests that represent optimal habitat for a species requiring 50-100 ha of deciduous forest for a pair to survive (Aulén 1988, Scherzinger 1990, Virkkala et al. 1993). These stands were relatively intact because of the difficulty in harvesting stands at high altitudes with a limited number of logging trails. Although there is no information about the effective population size, density, and population trends, the survival of the White-backed Woodpecker in Central Italy is uncertain because timber harvesting currently is removing the essential habitat. Despite the need for urgent measures of forest management to preserve the subspecies lilfordi in Italy, timber harvesting remains uncontrolled in several protected areas, and in some cases extensive logging of old-growth stands occurs with the tacit consent of the local authorities.

Finally, the White-backed Woodpecker can be considered an umbrella species (sensu Fernández et al. 1994, Martikainen et al. 1998). Such status not only facilitates efforts to preserve this woodpecker, but also other species less conspicuous or less well known to the public. For example, many threatened beetle species inhabit the same habitat as the Whitebacked Woodpecker (Martikainen et al. 1998). Also, the extension of timber rotation age beyond the present $20-25$ yrs could prevent genetic drift and inbreeding depression in tree populations that influence tree vitality and forest health (Scoppola 1999).

\section{ACKNOWLEDGMENTS}

We thank M. Cardaci, C. Costantini, R. Papi and F. Pinchera for their precious help in the different phases of the work. R. N. Conner, M. Ferrer, J. A. Smallwood, R. Virkkala, T. Wesolowski, and C. Ziegelmeyer provided helpful comments on the manuscript.

\section{LITERATURE CITED}

Ahlén, I., A. Andersson, G. Aulén, And B. PettersSON. 1978. White-backed Woodpecker Dendrocopos leucotos and Middle-Spotted Woodpecker Dendrocopos medius: the ecology of two endangered species in Sweden (in Swedish with an English summary). Anser S3:5-11.

Angelstam, P. And G. Mikusinski. 1994. Woodpecker assemblages in a natural and managed boreal and hemiboreal forest: a review. Ann. Zool. Fenn. 31: 157-172.

AulÉN, G. 1986. The distribution and status of the White-backed Woodpecker in Sweden. Vår Fågel. 45:201-226.

AULÉN, G. 1988. Ecology and distribution history of White-backed Woodpecker Dendrocopos leucotos in Sweden. Ph.D. diss., Swedish Univ. of Agricultural Sciences, Uppsala.

AULÉN, G. 1991. Increasing insect abundance by killing deciduous trees: a method of improving the food situation for endangered woodpeckers. Hol. Ecol. 14:68-80.

Bernoni, M. 1994. Primi dati sul Picchio Dorsobianco 
(Picoides leucotos lilfordi) nel Parco Nazionale d'Abruzzo. Pp. 491-492 in Atti VI Convegno Italiano di Ornitología (T. Mingozzi and C. Violani, Eds.). Museo Regionale Scienze Naturali, Torino, Italy.

Calvario, E., M. Gustin, S. Sarrocco, U. Gallo Orsi, F. Bulgarini, AND F. Fraticelli. 1999. Nuova Lista Rossa degli uccelli nidificanti in Italia. Riv. Ital. Orn. 69:3-43.

CARLson, A. 1998. Territory quality and feather growth in the White-backed Woodpecker Dendrocopos leucotos. J. Avian Biol. 29:205-207.

Carlson, A. 2000. The effect of habitat loss on a deciduous forest specialist species: the Whitebacked Woodpecker (Dendrocopos leucotos). For. Ecol. Manage. 131:215-221.

Carlson, A. and G. Aulén. 1992. Territorial dynamics in an isolated White-backed Woodpecker (Dendrocopos leucotos) population. Cons. Biol. 6: 450-454.

Castiglia, G., E. A. Di Carlo, and G. Tabarrini. 1976. Il Picchio Nero (Dryocopus martius) e il Picchio di Lilford (Dendrocopos leucotos lilfordi) nell' Appennino Centrale. Riv. Ital. Orn. 46:169.

Cody, M. L. 1985. Habitat selection in birds. Academic Press, New York.

Costantini, C. And M. Melletti. 1992. The Whitebacked Woodpecker, Picoides leucotos lilfordi, and the Lesser Spotted Woodpecker, Picoides minor, in the beechwoods of the Simbruini and Ernici Mountains (Central Italy). Riv. Ital. Orn. 62: $164-170$.

Costantini, C. And M. Melletti. 1994. Primi dati sulla presenza del Picchio Dorsobianco Picoides leucotos lilfordi e del Picchio Rosso Minore Picoides minor nelle faggete dei Monti Simbruini ed Ernici (Italia Centrale). Pp. 493-494 in Atti VI Convegno Italiano di Ornitología (T. Mingozzi and C. Violani, Eds.). Museo Regionale Scienze Naturali, Torino, Italy.

Costantini, C., M. Melletti, And R. Papi. 1993. Osservazioni preliminari sulla biologia riproduttiva del Picchio Dorsobianco Picoides leucotos lilfordi in Italia Centrale. Avocetta 17:81-83.

Costantini, C., M. Melletti, And R. PAPI. 1995. Tecniche di alimentazione e nicchia di foraggiamento del Picchio Dorsobianco Picoides leucotos lilfordi in Italia Centrale. Avocetta 19:138.

Cramp, S. AND K. E. L. Simmons. 1985. Handbook of the birds of Europe, the Middle East and North Africa. The birds of the Western Palearctic, vol. 4: terns to woodpeckers. Oxford Univ. Press, Oxford, United Kingdom.

Dentesani, B. 1990. Prima indagine sulla distribuzione del Picchio Rosso Minore, Picoides minor, in Provincia di Udine. Riv. Ital. Orn. 60:185-189.

FERnÁNDEZ, C. AND P. AZKONA. 1996. Influence of forest structure on the density and distribution of the White-backed Woodpecker Dendrocopos leucotos and Black Woodpecker Dryocopus martius in
Quinto Real (Spanish western Pyrenees). Bird Study 43:305-313.

Fernández, C., P. Azkona, And L. Lorente. 1994. Corología y caracterización del habitat del Pico Dorsiblanco (Dendrocopos leucotos lilfordi) en el Piríneo Occidental español. Ardeola 41:135-140.

GrangÉ, J.-L. 1993. Données préliminaires sur la biologie de reproduction du Pic à Dos Blanc Pyrénéen (Dendrocopos leucotos lilfordi) en Béarn. Nos Oiseaux 42:17-28.

Hågvar, S., G. Hågvar, And E. Mønnesso. 1990. Nest site selection in Norwegian woodpeckers. Hol. Ecol. 13:156-165.

HÅland, A. AND M. Ugelvik. 1990. The status and management of the White-backed Woodpecker Dendrocopos leucotos in Norway. Pp. 29-36 in Conservation and management of woodpecker populations, report 17 (A. Carlson and G. Aulén, Eds.). Swedish Univ. of Agricultural Sciences, Dept. of Wildlife Ecology, Uppsala, Sweden.

Hildén, O. 1965. Habitat selection in birds: a review. Ann. Zool. Fenn. 2:53-75.

KRAMS, I. 1998. Nest site selection of the Whitebacked Woodpecker Dendrocopos leucotos in the eastern part of Latvia. Orn. Svec. 8:11-16.

Martikainen, P., L. Kaila, AND Y. Haila. 1998. Threatened beetles in White-backed Woodpecker habitats. Cons. Biol. 12:293-301.

MATSUOKA, S. 1979. Ecological significance of the early breeding in White-backed Woodpecker Dendrocopos leucotos. Tori 28:63-75.

Mikusinski, G. AND P. Angelstam. 1998a. Economic geography, forest distribution and woodpecker diversity in central Europe. Cons. Biol. 12:200-208.

Mikusinski, G. And P. Angelstam. 1998b. European woodpeckers and anthropogenic habitat change: evidence of effects in different scales. Die Vogel. 118:277-283.

MülleR, W. 1982. Die Besiedlung der Eichenwälder im Kanton Zürich durch den Mittelspecht Dendrocopos medius. Ornit. Beob. 79:105-119.

NAZARova, I. D. 1977. Otrjad dljatloobraznye Piciformes. Pp. 274-286 in Ptitsy Wolsko-Komskogo Kraja (V. A. Popov, Ed.). Izdatelstvo Nauka, Moscow, Russia.

Norusis, M. J. 1992. SPSS for Windows. SPSS, Inc., Chicago, Illinois.

PAvLík, Š. 1999. Breeding ecology of the Whitebacked Woodpecker Dendrocopos leucotos in oak forest. Biologia 54:187-194.

Penteriani, V. and B. Faivre. 1997. Breeding density and nest site selection in a Goshawk Accipiter gentilis population of the Central Apennines (Abruzzo, Italy). Bird Study 44:136-145.

Penteriani, V., B. Faivre, and B. Frochot. 2001. An approach to identify factors and levels of nesting habitat selection: a cross-scale analysis of Goshawk preferences. Orn. Fenn. 78:159-167.

Peterken, G. F. 1996. Natural woodland: ecology and conservation in northern temperate regions. Cambridge Univ. Press, Cambridge, United Kingdom. 
PIncherA, F. 1997. Nest sites of Picinae in four areas of Central Apennines (Central Italy). Ph.D. diss., Univ. of La Sapienza, Rome, Italy.

Pinchera, F., L. Boitani, AND F. Corsi. 1997. Application to the terrestrial vertebrates of Italy of a system proposed by IUCN for a new classification of national Red List categories. Biodivers. Conser. 6:959-978.

Pinchera, F. and M. Pellegrini. 1999. Spacing and density of Picinae nest sites in two areas of Central Apennines (Central Italy). Riv. Ital. Orn. 69: 105-113.

SCHERZINGER, W. 1990. Is competition by the Great Spotted Woodpecker the cause for White-backed Woodpecker's rarity in Bavarian Forest National Park? Pp. 81-91 in Conservation and management of woodpecker populations, report 17 (A. Carlson and G. Aulén, Eds.). Swedish Univ. of Agricultural Sciences, Dept. of Wildlife Ecology, Uppsala, Sweden.

Scoppola, A. 1999. Tipologie vegetazionali di faggete appenniniche. Pp. 21-67 in Ecologia strutturale e funzionale di faggete Italiane (G. Scarascia Mugnozza, Ed.). Edagricole, Calderini, Bologna, Italy.

SOKAL, R. R. AND F. J. RoHLF. 1995. Biometry: the principles and practice of statistics in biological research, 3rd ed. Freeman, New York.

Spiridonov, J. AND R. VirkKala. 1997. The Whitebacked Woodpecker Dendrocopos leucotos. Pp.
454-455 in The EBCC atlas of European breeding birds (W. J. M. Hagemeiher and M. J. Blair, Eds.). Academic Press, London, United Kingdom. Sulli, C. AND M. Bernoni. 1993. Primi riscontri ai criteri di gestione delle risorse forestali adottati nel Parco Nazionale d'Abruzzo. Camerino, Ecologia del Paesaggio 21:373-378.

Tiainen, J. 1990. Distribution changes and present status of Dendrocopos leucotos in Finland. Pp. 2128 in Conservation and management of woodpecker populations, report 17 (A. Carlson and G. Aulén, Eds.). Swedish Univ. of Agricultural Sciences, Dept. of Wildlife Ecology, Uppsala, Sweden.

Virkkala, R., T. Alanko, T. Laine, and J. Tiainen. 1993. Population contraction of the White-backed Woodpecker Dendrocopos leucotos in Finland as a consequence of habitat alteration. Biol. Cons. 66:47-53.

Voous, K. H. 1947. On the history of the distribution of the genus Dendrocopos. Limosa 20:1-142.

Wesolowski, T. 1995. Value of Bialowieza forest for the conservation of White-backed Woodpecker Dendrocopos leucotos in Poland. Biol. Cons. 71: 69-75.

Wesolowski, T. And L. Tomialojć. 1986. The breeding ecology of woodpeckers in a primaeval temperate forest: preliminary data. Acta Ornith. 22: $1-21$. 